\title{
Diaphyseal fractures of the forearm in adults, comparative study of dynamic compression plate versus intramedullary nail
}

\author{
Sagar Venkataraman, Prabhu Ethiraj*, Arun Heddur Shanthappa Naik, \\ Sachin Prakash Angadi
}

\begin{abstract}
Department of Orthopaedics, Sri Devaraj Urs Academy of Higher Education and Research, Tamaka, Kolar, Karnataka,
\end{abstract} India

Received: 11 April 2019

Revised: 08 July 2019

Accepted: 19 July 2019

\section{*Correspondence:}

Dr. Prabhu Ethiraj,

E-mail: prabhu.thepreacher@gmail.com

Copyright: (c) the author(s), publisher and licensee Medip Academy. This is an open-access article distributed under the terms of the Creative Commons Attribution Non-Commercial License, which permits unrestricted non-commercial use, distribution, and reproduction in any medium, provided the original work is properly cited.

\begin{abstract}
Background: Forearm fractures are common nowadays because of road traffic accident. It is important to achieve anatomical reduction of both bone forearm fractures to regain function of upper limb. This study is undertaken to observe functional and radiological outcome using two different surgical modalities like dynamic compression plating (DCP), and intramedullary nailing in both bone forearm fractures and also to indivualize the optimal treatment method for different fracture pattern.

Methods: Our study included 60 patients with diaphyseal forearm fractures in adults presenting to orthopaedic outpatient department. Among 60 patients, 30 patients underwent open reduction and internal fixation by dynamic compression plate and other 30 patients underwent closed reduction/open reduction by square nail after detailed preoperative evaluation.

Results: In our study average union time in DCP group is 23.39 weeks and square nail group is 28.89 weeks. Union in DCP group was $27(90 \%)$ and square nail group $22(73.33 \%)$. Delayed union in DCP group was $03(10 \%)$ and in Square nail group was $6(20 \%)$, non-union in DCP group was 0 (nil) and in square nail group was $2(06 \%)$.

Conclusions: Open reduction and internal fixation with DCP plates for both bone diaphyseal forearm fractures gives good results with early union rates. We also found that in open fractures and complex fracture like segmental fractures square nailing was better option compared to dynamic compression plate to reduce infection rates, retain periosteal blood supply from soft tissue. Thus we conclude that both implants are equally important and we should prioritize based on preoperative planning.
\end{abstract}

Keywords: Diaphyseal forearm fractures, Dynamic compression plate, Square nail

\section{INTRODUCTION}

The number of forearm fractures is increasing faster rate in recent times due to various factors like rapid industrialization, increased incidence of violence, road traffic accidents, various sports activities, increasing of fall and direct blow because of which diaphyseal fractures of the forearm are commonly encountered by orthopaedic surgeon. Fractures of the forearm bones may result in severe loss of function unless adequately treated.
Anatomical reduction is important and also restoration of soft tissue and vascularity is also equally important. Open reduction and internal fixation is treatment of choice. It is important to achieve compression at fracture site, rotational stability, achieve length. If rotational alignment is altered, it affects function of elbow and forearm movements. Early mobilization of joint is important to prevent stiffness of joints. And also it is important to retain periosteal blood supply, less soft tissue damage at fracture site to achieve early union of fracture. Open 
reduction and internal fixation with dynamic compression plate is a common procedure done for fractures of both bones forearm. ${ }^{1}$ Even newer modalities of plate osteosynthesis such as locking plate and limited contact plate have been introduced however the DCP is still a choice for many surgeons. ${ }^{2}$ Various treatment modalities were introduced from time to time and each of them had some edge over the previous one. The encouraging results that have been reported with recent advances in operative management and instrumentation have led to an expansion of surgical indications for such fractures and a dilemma about the procedure of choice. Previous studies says plate fixation for both bone forearm fractures give good results, but however it has disadvantages like more operative time, more blood loss, soft tissue damage, periosteal stripping, radioulnar synostosis, neurovascular injury, non-union and infection. Only a few authors have focused on plate fixation in the management of open diaphyseal fractures of radius and ulna. ${ }^{3-8}$ Intramedullary nailing is also an option for both bone forearm fracture fixation with advantages like less operative time, less blood loss, less soft tissue damage, no periosteal stripping minimizes disruption of fracture biology. Intramedullary nail can be used in open diaphyseal fracture of radius or ulna. Fracture both bone forearm treated with various surgical modalities like open reduction and internal fixation with dynamic compression plating, limited contact dynamic compression plating, semi-tubular plating or closed reduction and internal fixation with intramedullary nail. There is no consensus as to whether intramedullary nail or plate is the optimal treatment method. In forearm both radius and ulna form important bone, along with both bone, introsseous membrane is also stabilizing structure. Any fracture at any level with disruption of introsseous membrane will results in loss of function. Therefore restoring near normal anatomy becomes important to regain full function. Rotational alignment should be achieved. ${ }^{8}$ Radius bone has bow shaped, whereas ulna is relatively straight and maintains length of forearm, supinator muscles and pronator muscles act in opposite direction. ${ }^{9}$ Fracture in proximal level will results in supination of proximal fragment and fracture in distal level of forearm will results in pronation of distal fragment. Open reduction and internal fixation with plate gives good reduction and rigid fixation, and also radial bow can be maintained, primary bone healing is achieved. When fracture gap is compressed by dynamic compression plate, capillaries grow in medullary callus and union rates are high. ${ }^{10,11}$

The objective of this study was undertaken to observe functional and radiological outcome using two different surgical modalities like dynamic compression plating, and intramedullary nailing and also to indivualize the optimal treatment method for different fracture pattern.

\section{METHODS}

Study was conducted in R. L. Jalappa hospital attached to Sri Devaraj Urs Medical College. This was retrospective study which included cases between June 2011 to June 2017. Out of 60 patients with diaphyseal forearm fractures 30 patients were treated by open reduction and internal fixation with dynamic compression plate and other 30 patients with open reduction/closed reduction intramedullary nailing. We analyzed data by collecting essential/required details like history, clinical examination findings, X-ray from patient records. The functional outcome was assessed according to Anderson scoring system which included evaluation of the movements and radiological union. Acute diaphyseal fractures of forearm treated with dynamic compression plate or intramedullary nailing who were 18-60 years of age and type 1, type 2 compound fractures were included in study and people with pathological fracture, associated neurovascular injury, crush injuries and multiple fractures with head injuries were excluded. Statistical software SPSS version 22 was used to analyse the data of our study (Table 1).

Table 1: Radiological outcome, functional outcome and post-operative complications. ${ }^{2}$

\begin{tabular}{|llll|}
\hline Results & Radiological & $\begin{array}{l}\text { Loss of flexion/extension } \\
\text { (in degrees) }\end{array}$ & $\begin{array}{l}\text { Loss of supination/pronation } \\
\text { (In degrees) }\end{array}$ \\
\hline Excellent & Union & $<10$ & $<25$ \\
\hline Satisfactory & Union & $<10-20$ & $<25-50$ \\
\hline Unsatisfactory & Union & $>30$ & $>50$ \\
\hline Failure & $\begin{array}{l}\text { Non-union with or without } \\
\text { loss of function }\end{array}$ & & \\
\hline
\end{tabular}

\section{RESULTS}

Out of 60 patients with forearm bone fracture treated in R. L. Jalapa Hospital, Kolar, 30 patients were operated with open reduction and internal fixation with dynamic compression plate (group 1) other 30 patients with open/ closed reduction with square nail (group 2). Out of 60 patients 42 were males, 18 were females. There was male preponderance. Youngest age of patient was 20 years old and oldest age was 60 years old. And average age was 38.45 years (Table 2 ).

In our study most of patient had met with RTA 42 (70\%), fall from height $6(10 \%)$, slip and fall down 07 (11.67\%), assault $5(08.33 \%)$. Right side forearm fractures 35 $(58.33 \%)$ was more compared to left side forearm fractures $25(41.67 \%) .17(28.33 \%)$ had proximal $1 / 3^{\text {rd }}$ fractures, $27(45 \%)$ had middle $1 / 3^{\text {rd }}$ fractures and 16 $(26.67 \%)$ had distal $1 / 3^{\text {rd }}$ fractures. Present study showed 
$32(53.33 \%)$ fractures were simple, $21(35 \%)$ fractures were comminuted and $7(11.67 \%)$ fractures were segmental. $40(66.67 \%)$ fractures were closed and 20 $(33.33 \%)$ fractures were open (compound fractures).

Table 2: Demographic details of study participants.

\begin{tabular}{|lll|}
\hline Variable & Group 1 (DCP) & Group 2 (square Nail) \\
\hline Number of patients & 30 & 30 \\
\hline Sex (male:female) & $20: 10$ & $22: 8$ \\
\hline Age(yrs) mean (range) & 38.03 & 38.06 \\
\hline Fracture side (right:left) & $16: 14$ & $19: 11$ \\
\hline Fracture site & & 11 \\
\hline Proximal 1/3rd & 06 & 12 \\
\hline Middle 1/3rd & 15 & 07 \\
\hline Distal 1/3rd & 09 & 18 \\
\hline Type of fracture & & 07 \\
\hline Simple & 14 & 05 \\
\hline Comminuted & 14 & 11 \\
\hline Segmental & 02 & 19 \\
\hline Closed fractures & 27 & \\
\hline Open fractures & 03 & \\
\hline
\end{tabular}

Table 3: Mechanism of injury of study participants.

\begin{tabular}{|lll|}
\hline Mechanism of injury & Group 1 (DCP) & Group 2 (square nail) \\
\hline Road traffic accident & 21 & 21 \\
\hline Fall from height & 3 & 3 \\
\hline Slip and fall down & 4 & 3 \\
\hline Assault & 2 & 3 \\
\hline
\end{tabular}

Table 4: Comparison of radiological union in two groups.

\begin{tabular}{|c|c|c|c|}
\hline Union & DCP-plating (\%) & Intramedullary nail (square nail) (\%) & P value \\
\hline United & $27(90)$ & $22(73.33)$ & \multirow{4}{*}{0.04} \\
\hline Delayed union & $03(10)$ & $06(20)$ & \\
\hline Non-union & 00 & $02(6.67)$ & \\
\hline Average time to unite in weeks & 23.39 & 28.89 & \\
\hline
\end{tabular}

Table 5: Comparison of functional results assessed by Anderson scoring system in two groups.

\begin{tabular}{|llll|}
\hline Anderson scoring & DCP plating (\%) & Intramedullary nail (\%) & P value \\
\hline Excellent & $24(80)$ & $19(63.3)$ & 0.06 \\
\hline Satisfactory & $06(20)$ & $07(23.3)$ & $2(6.7)$ \\
\hline Unsatisfactory & 00 & $2(6.7)$ & 00
\end{tabular}

In our study average union time in group 1 (DCP group) is 23.39 weeks and group 2 (square nail group) is 28.89 weeks. Early complication like superficial infection in group 1 was $02(06 \%)$ which were more in group 2, 7 (23.33\%), late complications like forearm pain in group 1 was $02(06 \%)$ and in group 2 was $4(13 \%)$, elbow and wrist stiffness in group 1 was $02(06 \%)$ and in group 2 was $3(10 \%)$, delayed union in group 1 was $03(10 \%)$ and in group 2 was $6(20 \%)$, non-union in group 1 was 0 (nil) and in group 2 was $2(06 \%)$ (Table 3$)$.

$30(100 \%)$ of study participants who underwent DCPPlating had radiological findings of union compared with
Intramedullary nailing $(93.33 \%)$ and this association was statistically significant (Table 4).

$24(80 \%)$ of patients who underwent DCP Plating had Excellent Anderson scoring compared with intramedullary nail however this association was not statistically significant (Table 5).

\section{DISCUSSION}

The present study included 60 patients, 30 patients with forearm diaphyseal fractures were treated by open reduction and internal fixation with dynamic compression 
plate and other 30 patients underwent open reduction/closed reduction with square nailing. In our study age group was between 20 years to 60 years and mean age group was 38.4 years, when compared to other series Herbert Dodge mean age 24 years, in chapman series average age was 33 years. ${ }^{10,12}$ And our study showed $70 \%$ males and $30 \%$ females compared with Herbert dodge series $89 \%$ males and $11 \%$ females. $^{10}$ There was male preponderance with male to female ratio $7: 3$. Study also showed involvement of more right side $60 \%$ compared to left side $40 \%$, cause of injury was more due to road traffic accident $73 \%$, other modes of injury was fall from height $11 \%$ and assault $09 \%$, sports injury $07 \%$. In our study $66.67 \%$ were closed fractures and $33.33 \%$ were open fractures. In our study $03(10 \%)$ patient in group 1 showed delayed union compared to 06 $(20 \%)$ in group 2 and $02(06 \%)$ in group 1 developed elbow and wrist stiffness compared to 03 (10\%) in group 2 in early post op follow up later after physiotherapy there was increase in elbow and wrist range of movements. $02(06 \%)$ patients in group 1 showed superficial infection compared to $07(23.33 \%)$ in group 2. In group 1 showed no non-union, whereas group 2 showed $02(06 \%)$.

Previous study as per literature union rates in plating group is $87 \%-100 \%$ have been reported, time to get union has been reported between 7.4 weeks-33 weeks. ${ }^{13-20}$ In our study DCP plating group, union was achieved at rate of $100 \%$ and at mean of 23.39 weeks.

As per literature union rates in intramedullary nailing group is $90 \%-100 \%$ and union time is between 10 weeks to 32 weeks have been reported. ${ }^{21-24}$ In our study intramedullary group, $93.33 \%$ union was achieved at a mean of 28.89 weeks. A statistically significant difference was determined between groups with respect to union rates, time to union. And there is no statistically significant difference with respect to functional results assessed by Anderson scoring system.

In our study we noted that union rates were high by using dynamic compression plates. And also rotational alignment, stability and early elbow mobilization was achieved. In square nailing union rates were less, prolonged and took more time to unite compared to dynamic compression plates and required additional stability in the form of above elbow slab or cast and thereby delayed in elbow and wrist mobilization. But in square nailing there was less blood loss, very minimal scar, less soft tissue exposure, implant removal was easier compared to dynamic compression plate. We also found that in open fractures and segmental fractures square nailing was better option compared to dynamic compression plates, in view to reduce infection rates and also to retain periosteal blood supply from soft tissue. Dynamic compression plates achieves compression at fracture site, maintains rotational stability, maintains radius bow, but requires soft tissue exposure, more intraoperative blood loss, periosteal stripping and scar mark will be present. In intramedullary nailing since it is straight nail, difficult to achieve radius bow, rotational alignment, compression at fracture site but advantages are less soft tissue exposure, less intraoperative blood loss, no periosteal stripping and very minimal scar will be present.

\section{CONCLUSION}

There is increased incidence nowadays in forearm fracture due to high velocity road traffic accident, fall, and assault. In present days it is important to regain near total function of upper limb. If we reconstruct normal anatomy of bones, it is possible to achieve good function of upper limb and back to routine work early. Every attempt should be made to achieve maximum function of upper limb. Our study has showed that dynamic compression plate can achieve compression at fracture site, maintain rotational stability and length and early mobilization of elbow and wrist joint. Square nailing has also advantages like less intraoperative blood loss, less soft tissue exposure, no periosteal stripping, minimal scar, implant removal was easy compared to dynamic compression plate. However union rates were more with dynamic compression plate then square nailing. We also found that in open fractures and complex fracture like segmental fractures square nailing was better option compared to dynamic compression plate to reduce infection rates, retain periosteal blood supply from soft tissue. Thus we conclude that both implants are equally important and we should prioritize based on preoperative planning.

\section{Funding: No funding sources}

Conflict of interest: None declared

Ethical approval: The study was approved by the institutional ethics committee

\section{REFERENCES}

1. Russel TA. Campbell's Operative Orthopaedics. 8th edition. 2nd Volume. Classification of Diaphyseal fractures. 2017: 728-730.

2. Saikia KC, Bhuyan SK, Bhattacharya TD, Borgohain M, Jitesh P, Ahmed F. Internal fixation of fractures of both bones forearm: Comparison of locked compression and limited contact dynamic compression plate. Indian J Orthop. 2011;45(5):417.

3. Naiman PT, Schein AJ, Siffert RS. Use of ASIF compression plates in selected shaft fractures of the upper extremity. A preliminary report. Clin Orthop. 1970;71:208-16.

4. Duncan R, Geissler W, Freeland AE, Savoie FH. Immediate internal fixation of open fracture of the diaphysis of the forearm. $\mathrm{J}$ Orthop Trauma. 1992;6:25-31.

5. Reilly TJ. Isolated and combined fractures of the diaphysis of the radius and ulna. Hand Clin. 2002;18:179-94. 
6. Knight RA, Purvis GD. Fractures of both bones of the forearm in adults. J Bone Joint Surg Am. 1949;31:755-64.

7. Moore TM, Klein JP, Patzakis MJ, Harvery JP. Results of compression- plating of Galeazzi fractures. J Bone Joint Surg Am. 1985;67:1015-21.

8. Evans EM. Rotational deformity in the treatment of fractures of both bones of the forearm. J Bone Joint Surg. 1945;27(3):373-9.

9. Patrick J. A study of supination and pronation, with especial reference to the treatment of forearm fractures. J Bone Joint Surg Am. 1996;28(4):737-48

10. Dodge HS, Cady GW. Treatment of fractures of the radius and ulna with compression plates: A retrospective study of one hundred and nineteen fractures in seventy eight patients. J Bone Joint Surg Am. 1972;54:1167-76.

11. Ross ER, Gourevitch D, Hastings GW, Wynn-Jones CE, Ali S. Retrospective analysis of plate fixation of diaphyseal fractures of the forearm bones. Injury. 1989;20(4):211-4

12. Chapman MW, Gordon JE, Zissimos AG. Compression plate fixation of acute fractures of the diaphyses of the radius and ulna. J Bone Joint Surg Am. 1989;71(2):159-69.

13. Schemitsch EH, Richards RR. The effect of malunion on functional outcome after plate fixation of fractures of both bones of the forearm in adults. $\mathrm{J}$ Bone Joint Surg Am. 1992;74:1068-78.

14. Anderson LD, Sisk D, Tooms RE, Park WI. Compression plate fixation in acute diaphyseal fractures of the radius and ulna. J Bone Joint Surg Am. 1975;57:287-97.

15. Ozkaya U, Kilic A, Ozdogan U, Beng K, Kabukcuoglu Y. Comparison between locked intramedullary nailing and plate osteosynthesis in the management of adult forearm fractures. Acta Orthop Traumatol Turc. 2009;43:14-20.

16. Grace TG, Eversmann WW Jr. Forearm fractures: treatment by rigid fixation with early motion. J Bone Joint Surg Am. 1980;62:433-8.
17. Stevens CT, ten Duis HJ. Plate osteosynthesis of simple forearm fractures: LCP versus DC plates. Acta Orthop Belg. 2008;74:180-3.

18. Stern PJ, Drury WJ. Complications of plate fixation of forearm fractures. Clin Orthop Relat Res. 1983;175:25-9.

19. Leung F, Chow SP. A prospective randomized trial comparing the limited contact dynamic compression plate with the point contact fixator for forearm fractures. J Bone Joint Surg Am. 2003;85:2343-8.

20. Droll KP, Perna P, Potter J, Hamiman E, Schemitsch EH, McKee MD. Outcomes following plate fixation of fractures of both bones of the forearm in adults. $\mathbf{J}$ Bone Joint Surg Am. 2007;89:2619-24.

21. Kose A, Aydin A, Ezirmik N, Can CE, Topal M, Tipi T. Alternative treatment of forearm double fractures: new design intramedullary nail. Arch Orthop Trauma Surg. 2014;134:1387-96.

22. Lee YH, Lee SK, Cjung MS, Baek GH, Gong HS, Kim KH. Interlocking contoured intramedullary nail fixation for selected diaphyseal fractures of the forearm in adults. $\mathrm{J}$ Bone Joint Surg Am. 2008;90:1891-8.

23. Kose A, Aydin A, Ezirmik N, Topal M, Can CE, Yilar S. Intramedullary nailing of adult isolated diaphyseal radius fractures. Ulus Travma Acil Cerrahi Derg. 2016;22:184-91.

24. Kose A, Aydin A, Ezirmik N, Topal M, Can CE. Treatment of isolated ulnar fractures in adults with a new intramedullary nail. Minerva Orto-pedica e Traumatologica. 2015;66:123-31.

Cite this article as: Venkataraman S, Ethiraj P, Naik AHS, Angadi SP. Diaphyseal fractures of the forearm in adults, comparative study of dynamic compression plate versus intramedullary nail. Int J Res Orthop 2019;5:916-20. 